\title{
Optimum Groundwater Pumping Rate in Safwan-Zubair Area, Basrah Province, Using Simulated Annealing Technique
}

\author{
Ali H. Al-Aboodi
}

Department of Civil Engineering, College of Engineering, University of Basrah, Basrah, Iraq

E-mail: alialaboodi90@gmail.com

\section{ABSTRACT}

Safwan-Zubair area is located in the south -west part of Basrah Province in the south of Iraq, this area is involved within the Dibdibba plain which is considered as a part of Iraqi Western Desert. Dibdibba formation consists mainly from sand and gravel with some cementing materials like silt and clay, especially in the west of Zubair area. A linked simulation-optimization model for obtaining the optimum pumping rate of groundwater is presented in this paper. Processing Modflow for Windows (PMWIN v.5) is selected to simulate the aquifer behavior being studied. This model is integrated with an optimization model which is based on the simulated annealing (SA) technique. The calibrated values of hydraulic conductivity vary over the range (15-150) $\mathrm{m} /$ day; while, the calibrated values of specific yield vary over the range $(0.125-0.45)$. The objective function converges to a maximum value of $\left(0.636925 \mathrm{E}+8 \mathrm{~m}^{3} / \mathrm{year}\right)$. The percentage ratio of inactive wells is $10.9 \%$, many wells in the study area that occupy incorrect positions, these wells must be turn off for obtaining optimum pumping rate in the study area.

Keywords: Optimum; Groundwater; MODFLOW; Simulated Annealing; Basrah; Iraq

\section{Introduction}

Recently, the study of water resources becomes basic necessity that must be done, because it is indispensable an economical fortune. Most of the water on earth (97\%) is contained in the oceans and is of little use to essential drinking, municipal or irrigational uses, $3 \%$ of the water available is fresh water and out of this about $2 \%$ of the water is in the form of glaciers and polar ice cap, therefore, only $1 \%$ of the total water available can be of direct use to humans. Groundwater constitutes about $7 \%$ of the total fresh water available on earth ${ }^{[1]}$. The water management principles over the world are not uniform due to uneven distribution of water resources. Particularly in arid and semi-arid regions, scant rainfall distribution has made groundwater as one of the important natural resources constraints for growth ${ }^{[2]}$. In many countries groundwater is considered as one of the major water resources. So, it must be carefully managed and protected for most beneficial use. With population growing and economic developments, substantial exploitation and management of groundwater, and surface water resources has become increasingly important. Recent droughts seasons, limited surface water resources, and a projected doubling of population over the next fifty years, there is a considerable interest in using groundwater resources.

Various geological and hydrological studies were conducted on Safwan-Zubair area. These studies are done by the following researchers. Haddad, 1977 made an extensive study about the hydrological features of the Safwan area, which includes water balance for this region. He stated that the decrease in quantity of groundwater in Safwan area due to increase in quantities of fructification for agricultural purposes and the decrease in the recharge quantities of this groundwater ${ }^{[3]}$. Hassan et. al, 1988 studied the hydrological conditions of Safwan-Zubair area, particularly on the behavior of rainfall[ ${ }^{[4]}$. Al-Jawad et. al, 1989 presented study on the hydraulic properties of the upper aquifer using pumping test on a large diameter wells ${ }^{[5]}$. Al-Suhail, 1999 used a geochemical model for estimation of mixing interaction between the

EnPress Publisher LLC.This work is licensed under the Creative Commons Attribution-NonCommercial 4.0 International License (CC BY-NC 4.0). http://creativecommons.org/licenses/ by/4.0/ 
unconfined aquifer and underlying aquifer ${ }^{[6]}$.

Development of both conceptual and computational models for groundwater hydrology has started since the beginning of the twentieth century to the present day. Initially, computational models relied on analytical methods but there is now a greater use of numerical models. Real groundwater problems are frequently so complex that they can only be analyzed when simplified assumptions are introduced. Imaginations and experiences are required to identify the key process which must be included in conceptual models.

Development of groundwater resources requires answers to key questions such as:-

1. What are the best locations of installing wells to develop this groundwater resource?

2. How much water can be extracted at these locations?

These two questions were answered by developing two models in the study area. The first model, a numerical model is applied for studying groundwater flow patterns. The second model is a combined simulation-optimization approach to quantify the water availability in the potential locations.

The objective of this research is to develop decision support tools for identifying optimal groundwater discharge to meet the future demands in the Safwan-Zubair area by using simulated annealing (SA) technique.

\section{Description of Study Area}

The study area is located in the south -west part of Basrah province in the south of Iraq, which located between longitude-line $\left(47^{\circ} 30^{\prime}-48^{\circ} 00^{\prime}\right)$ and latitude line $\left(30^{\circ} 03^{\prime}-30^{\circ} 30^{\prime}\right)$, the area is about $2000 \mathrm{~km}^{2}$ as shown in Figure (1). The average annual rate of rainfall is $148 \mathrm{~mm}$ or less, while the evaporation rates are very high (reaches to $3500 \mathrm{~mm}$ ). Because no perennial river exists, groundwater is a major natural resource within the interested area. Safwan-Zubair area is involved within the Dibdibba plain which is considered as a part of Iraqi Western Desert. The topography is relatively flat with a gentle overall slope toward the Euphrates River to its north, and the Shatt Al-Arab River to its east and southeast. Natural ground surface elevations range from $(17$ to $23 \mathrm{~m})$ above sea level.

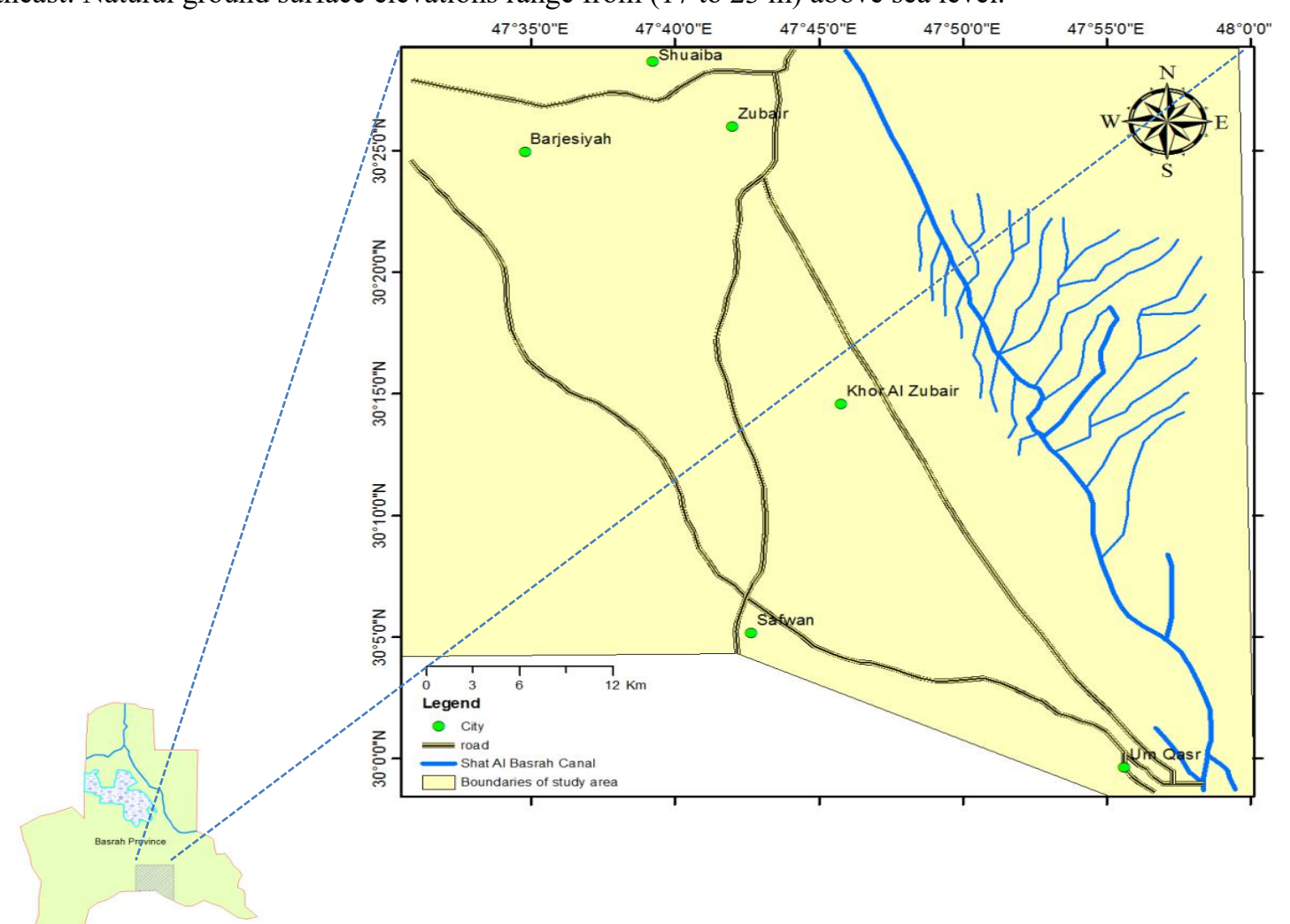

Figure 1; Location of study area in reference to the map of Basrah Province. 
Dibdibba Formation sediments are generally known as being changed gradually from marine sediments into river sediments which are crumbs increased [in quantity and the size of granules changed from oldness into moderns, which does not have any index fossils ${ }^{[7]}$. It consists mainly from sand and gravel with some cementing materials like silt and clay, especially in the west of Zubair area ${ }^{[8]}$. The upper part of Dibdibba formation was divided into two hydrogeological units. The first one is unconfined aquifer (Quaternary in age) which contains brackish water, and its saturated thickness extended from $(15 \mathrm{~m})$ to $(20 \mathrm{~m})$. The second aquifer is semi-confined (Tertiary) which contains saline water and it is separating from the first one by hard clay bed called locally (Jojeb) ${ }^{[9]}$. The suggested model which is advocated to simulate the flow regime for the unconfined aquifer is fixed for one layer. It is assumed that the base of the aquifer is an impermeable boundary, i.e., the activity of the deeper aquifer is negligible.

\section{Application of Numerical Model}

Processing Modflow for Windows (PMWIN v.5) is selected to simulate the aquifer behavior being studied. MODFLOW uses finite difference method to solve the groundwater flow mathematical model. Processing MODFLOW simulates groundwater flow in aquifer systems using the finite-difference method. In this method, an aquifer system is divided into rectangular blocks by a grid. The grid of block is organized by row index (I), column index (J), and layer index $(\mathrm{K})$, and each block is commonly called a "cell." The spatial domain of the aquifer system in the study area was discretized using a square-centered grid. The grid consists of 80 columns and 80 rows. Where, the area of one cell is equal to $\left(500 \times 500 \mathrm{~m}^{2}\right)$. The modeling is fixed for upper layer only (unconfined aquifer), it is assumed that the base of the upper aquifer is an impermeable boundary and heads do not vary in the vertical direction. In the present model, the northern, southern west and southern edges of the area almost parallel with the flow lines, therefore, these boundaries are represented as no flow boundaries. The eastern edge of the model area is considered as a constant head boundary because the canal of Shatt Al-Basrah River lies along this edge. The western boundary is modeled as head-dependent boundary to allow inflow to the modeled region at a rate proportional to the dead difference between the aquifer outside the simulated area and the model boundary. The hydraulic heads of groundwater in the study are necessary for calibrating the MODFLOW model. Thus, field work has been conducted to measure the hydraulic heads of groundwater. The field work was started on November/2013 and finished on October/2014. Thirteen monitoring wells were selected for measuring the groundwater hydraulic heads on monthly basis. The layout of these wells in model grid is shown in Figure (2) ${ }^{[10]}$.

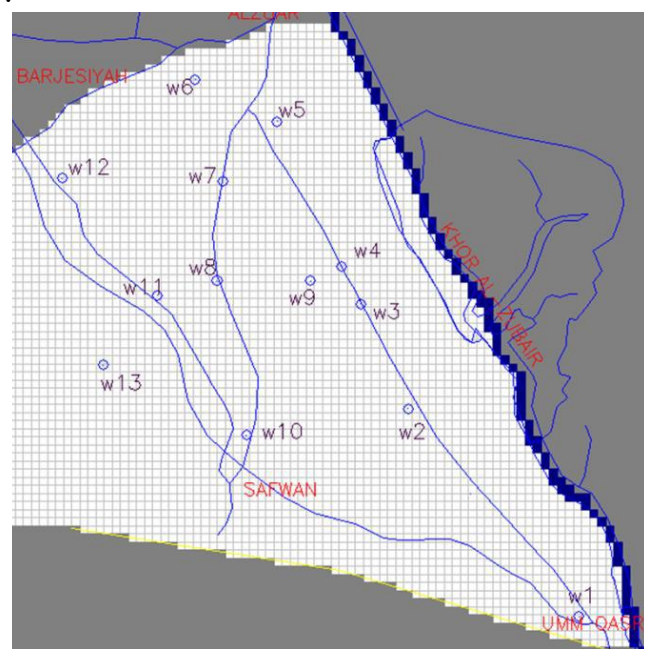

Figure 2; Layout of monitoring wells on Processing MODFLOW model grid.

Most irrigation wells of Safwan-Zubair area penetrate the quadral sediments and then Dibdibba Formation. Large diameter hand dug wells are commonly used for abstract groundwater in the study area. Operating wells are located at various spaces from each other, ranging from (500 to less $100 \mathrm{~m}$ ). Therefore, interfering among adjacent wells is possible under the existing pumping activities. Pumping rates of wells are variable and may range from (5 to $81 / \mathrm{s})$. The 
average of pumping rate is taken as $(71 / \mathrm{s})$. The total number of abstracted wells is equal to 350, Figure (3) shows the spatial distribution for the wells in the study area. Abstracted groundwater flow from all of the hand-dug and tube wells in this area use for domestic and agricultural purpose. In the present study, the unit time of simulation is days, where ten stresses periods are used. The first stress periods are seven months that represents the winter season, this mean that each period has duration of 30 days with specific value of direct recharge rate. The amount of direct recharge changes with time during the first seven stress periods. While, the remaining five months represents the summer season that is no direct recharge. The calibrated values of hydraulic conductivity vary over the range (15-150) $\mathrm{m} / \mathrm{day}$. While, the calibrated values of specific yield vary over the range $(0.125-0.45)$.

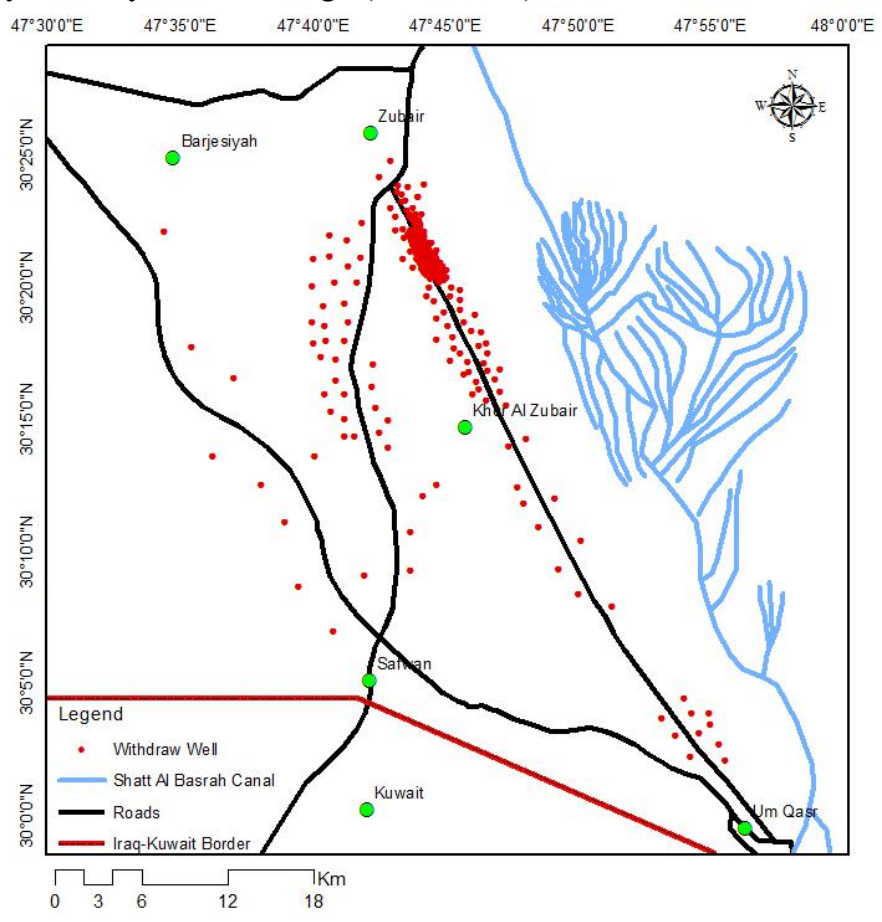

Figure 3; Spatial distribution of existing wells in the study area.

\section{Application of Optimization Technique}

The Modular Groundwater Optimizer (MGO) is a general-purpose simulation optimization code developed for field scale applications ${ }^{[11]}$. This modular is used in this research. In the proposed model, MODFLOW packages are used to simulate the flow in the groundwater system. This model is then integrated with an optimization model which is based on the simulated annealing (SA) technique; SA comes from an analogy between the physical annealing process of solids and optimization problems. Physical annealing is a process of attaining low energy states of a solid by initially melting the substance, and then lowering the temperature slowly, in such a way that the temperature remains close to the freezing point for a long period of time. At the end of the annealing process, the solid reaches its crystal state. In optimization, the objective function represents the energy in the thermodynamic process, while the optimal solution corresponds to the crystal state. The objective function is presented in equation (1). There are 350 pumping wells (actual number of wells in the study area), whose locations are shown in Figure (3). The objective function and constraints can be formulated as follow:

Maximize $\mathrm{J}=\Delta \mathrm{t} \sum_{\mathrm{i}=1}^{350}\left|\mathrm{Q}_{\mathrm{i}}\right|$

Subject to

$\mathrm{h}_{\min } \leq \mathrm{h}_{\mathrm{m}} \leq \mathrm{h}_{\max }$

$0 \leq\left|Q_{\mathrm{i}}\right| \leq 2000$

Where:

Equation (1), the objective function $(\mathrm{J})$ is expressed in terms of the absolute pumping rates multiplied by $\Delta \mathrm{t}$, the length of stress period in the flow model. 
Equation (2), is head limited constraint requiring that the hydraulic head at any monitoring well location, $\mathrm{h}_{\mathrm{m}}$, must be above $h_{\min }$ and below $h_{\max }$, where:

$\mathrm{h}_{\min }=\mathrm{h}_{\mathrm{i}}-0.2$

And

$\mathrm{h}_{\max }=\mathrm{h}_{\mathrm{i}}+0.2$

Where

$\mathrm{h}_{\mathrm{i}}$ is the initial hydraulic head. In equations (2a) and (2b), set the value of $0.2 \mathrm{~m}$ based on the groundwater levels change in the study area for the observation period (one year), there is no significant change in the hydraulic heads of groundwater during the period of observation, and to take a value is more realistic correspond with the changing reality of these hydraulic heads and away from excess of the water. Equation (3) specified zero as the minimum and 2000 $\mathrm{m}^{3} /$ day as the maximum for the magnitude of each pumping rate to be optimized. Generally, several test runs are needed to select an appropriate value for use as the maximum pumping rate. If it is set too high, the optimization solution may be inefficient. The number of discretization intervals (NPStep) for each pumping rate parameter is chosen to be 26. Since the minimum and maximum values for each parameter have been specified as 0 and $2000 \mathrm{~m}^{3} /$ day, respectively, the precision (or resolution) of the identified pumping rates is (2000-0)/ (26-1), or $80 \mathrm{~m}^{3} /$ day. In other words, the final pumping rates obtained by the SA solution may differ from the actual optimal values by as much as (but not to exceed) $80 \mathrm{~m}^{3} /$ day.

The objective function converges to a maximum value of $\left(0.636925 \mathrm{E}+8 \mathrm{~m}^{3} /\right.$ year $)$ after a total of 15 generations satisfying all the constraints. The final solution has only 312 active wells. The distribution of the optimized pumping rates is shown in table (1). It could be noticed that there are many wells in the study area that occupy incorrect positions, which are affected on the process of pumping water. Nine control points have been installed within the boundary of the model and they are distributed regularly to monitor the hydraulic head if it exceeds the limits established in the constraints (see table 2). The distribution of hydraulic head based on the optimized pumping rates for first stress period is shown in table (2).

\begin{tabular}{|l|l|l|l|l|l|l|l|l|}
\hline I & J & Discharge & I & J & Discharge & I & J & Discharge \\
\hline 10 & 27 & $-8.800 \mathrm{E}+02$ & 21 & 25 & $-4.000 \mathrm{E}+02$ & 30 & 22 & $-3.200 \mathrm{E}+02$ \\
\hline 10 & 18 & $-2.400 \mathrm{E}+02$ & 21 & 34 & $0.000 \mathrm{E}+00$ & 30 & 24 & $-7.200 \mathrm{E}+02$ \\
\hline 11 & 31 & $-4.000 \mathrm{E}+02$ & 22 & 22 & $-8.000 \mathrm{E}+01$ & 30 & 29 & $-8.000 \mathrm{E}+02$ \\
\hline 12 & 29 & $-2.000 \mathrm{E}+03$ & 22 & 26 & $-4.000 \mathrm{E}+02$ & 30 & 31 & $-1.360 \mathrm{E}+03$ \\
\hline 12 & 37 & $-1.600 \mathrm{E}+02$ & 22 & 28 & $-1.600 \mathrm{E}+02$ & 30 & 33 & $-3.200 \mathrm{E}+02$ \\
\hline 13 & 22 & $0.000 \mathrm{E}+00$ & 22 & 29 & $-4.000 \mathrm{E}+02$ & 30 & 35 & $-1.600 \mathrm{E}+02$ \\
\hline 13 & 25 & $-9.600 \mathrm{E}+02$ & 23 & 20 & $-8.000 \mathrm{E}+01$ & 30 & 36 & $-2.400 \mathrm{E}+02$ \\
\hline 13 & 27 & $-1.600 \mathrm{E}+02$ & 23 & 25 & $-3.200 \mathrm{E}+02$ & 30 & 37 & $-8.000 \mathrm{E}+01$ \\
\hline 13 & 31 & $-8.000 \mathrm{E}+01$ & 23 & 26 & $-8.000 \mathrm{E}+01$ & 30 & 39 & $-7.200 \mathrm{E}+02$ \\
\hline 13 & 33 & $-7.200 \mathrm{E}+02$ & 23 & 37 & $-8.000 \mathrm{E}+01$ & 31 & 20 & $-9.600 \mathrm{E}+02$ \\
\hline 14 & 28 & $-8.800 \mathrm{E}+02$ & 24 & 17 & $-8.000 \mathrm{E}+01$ & 31 & 29 & $-2.400 \mathrm{E}+02$ \\
\hline 14 & 32 & $-4.000 \mathrm{E}+02$ & 24 & 28 & $-1.920 \mathrm{E}+03$ & 31 & 31 & $0.000 \mathrm{E}+00$ \\
\hline 15 & 25 & $-2.400 \mathrm{E}+02$ & 24 & 31 & $-5.600 \mathrm{E}+02$ & 31 & 35 & $-6.400 \mathrm{E}+02$ \\
\hline 18 & 25 & $0.000 \mathrm{E}+00$ & 24 & 33 & $-8.000 \mathrm{E}+01$ & 31 & 36 & $0.000 \mathrm{E}+00$ \\
\hline 15 & 30 & $-8.000 \mathrm{E}+01$ & 24 & 35 & $-2.400 \mathrm{E}+02$ & 31 & 37 & $-8.000 \mathrm{E}+02$ \\
\hline 16 & 20 & $-8.000 \mathrm{E}+01$ & 25 & 20 & $0.000 \mathrm{E}+00$ & 31 & 43 & $-5.600 \mathrm{E}+02$ \\
\hline 16 & 21 & $-3.200 \mathrm{E}+02$ & 25 & 23 & $-1.120 \mathrm{E}+03$ & 32 & 16 & $-8.000 \mathrm{E}+01$ \\
\hline 16 & 33 & $-8.000 \mathrm{E}+01$ & 25 & 25 & $-5.600 \mathrm{E}+02$ & 32 & 19 & $-1.600 \mathrm{E}+02$ \\
\hline
\end{tabular}




\begin{tabular}{|c|c|c|c|c|c|c|c|c|}
\hline 16 & 35 & $-3.200 \mathrm{E}+02$ & 25 & 26 & $-1.680 \mathrm{E}+03$ & 32 & 22 & $-4.800 \mathrm{E}+02$ \\
\hline 16 & 40 & $-4.800 \mathrm{E}+02$ & 25 & 27 & $0.000 \mathrm{E}+00$ & 32 & 26 & $-3.200 \mathrm{E}+02$ \\
\hline 17 & 17 & $-2.400 \mathrm{E}+02$ & 26 & 26 & $0.000 \mathrm{E}+00$ & 32 & 31 & $-4.800 \mathrm{E}+02$ \\
\hline 17 & 22 & $-2.400 \mathrm{E}+02$ & 26 & 27 & $-1.680 \mathrm{E}+03$ & 32 & 33 & $-5.600 \mathrm{E}+02$ \\
\hline 17 & 26 & $-8.000 \mathrm{E}+01$ & 26 & 29 & $-8.000 \mathrm{E}+02$ & 32 & 35 & $-1.360 \mathrm{E}+03$ \\
\hline 17 & 27 & $-4.800 \mathrm{E}+02$ & 26 & 31 & $-8.000 \mathrm{E}+01$ & 32 & 36 & $0.000 \mathrm{E}+00$ \\
\hline 17 & 28 & $-1.120 \mathrm{E}+03$ & 26 & 33 & $-1.280 \mathrm{E}+03$ & 32 & 37 & $-5.600 \mathrm{E}+02$ \\
\hline 17 & 32 & $-2.400 \mathrm{E}+02$ & 26 & 36 & $-4.000 \mathrm{E}+02$ & 32 & 38 & $-6.400 \mathrm{E}+02$ \\
\hline 18 & 20 & $-1.600 \mathrm{E}+02$ & 26 & 38 & $0.000 \mathrm{E}+00$ & 33 & 20 & $-5.600 \mathrm{E}+02$ \\
\hline 18 & 24 & $-5.600 \mathrm{E}+02$ & 26 & 40 & $-4.000 \mathrm{E}+02$ & 33 & 24 & $-2.400 \mathrm{E}+02$ \\
\hline 18 & 26 & $-4.800 \mathrm{E}+02$ & 27 & 18 & $-4.000 \mathrm{E}+02$ & 33 & 30 & $-1.600 \mathrm{E}+02$ \\
\hline 18 & 27 & $-5.600 \mathrm{E}+02$ & 27 & 20 & $-1.680 \mathrm{E}+03$ & 33 & 31 & $-6.400 \mathrm{E}+02$ \\
\hline 18 & 30 & $-8.000 \mathrm{E}+01$ & 27 & 25 & $-8.000 \mathrm{E}+01$ & 33 & 35 & $0.000 \mathrm{E}+00$ \\
\hline 18 & 31 & $0.000 \mathrm{E}+00$ & 27 & 27 & $-8.000 \mathrm{E}+01$ & 33 & 36 & $-2.400 \mathrm{E}+02$ \\
\hline 18 & 34 & $0.000 \mathrm{E}+00$ & 27 & 30 & $-4.000 \mathrm{E}+02$ & 33 & 37 & $-2.400 \mathrm{E}+02$ \\
\hline 19 & 21 & $-2.400 \mathrm{E}+02$ & 28 & 18 & $-1.280 \mathrm{E}+03$ & 33 & 38 & $0.000 \mathrm{E}+00$ \\
\hline 19 & 22 & $-3.200 \mathrm{E}+02$ & 28 & 20 & $-1.600 \mathrm{E}+02$ & 33 & 40 & $-1.040 \mathrm{E}+03$ \\
\hline 19 & 27 & $-1.520 \mathrm{E}+03$ & 28 & 23 & $-8.000 \mathrm{E}+01$ & 34 & 19 & $0.000 \mathrm{E}+00$ \\
\hline 19 & 31 & $-4.000 \mathrm{E}+02$ & 28 & 28 & $-5.600 \mathrm{E}+02$ & 34 & 21 & $-9.600 \mathrm{E}+02$ \\
\hline 19 & 32 & $-1.040 \mathrm{E}+03$ & 28 & 31 & $-5.600 \mathrm{E}+02$ & 34 & 22 & $-8.000 \mathrm{E}+01$ \\
\hline 19 & 38 & $-8.000 \mathrm{E}+01$ & 28 & 33 & $-1.360 \mathrm{E}+03$ & 34 & 26 & $0.000 \mathrm{E}+00$ \\
\hline 20 & 19 & $-1.600 \mathrm{E}+02$ & 28 & 34 & $0.000 \mathrm{E}+00$ & 34 & 28 & $-4.000 \mathrm{E}+02$ \\
\hline 20 & 22 & $-1.760 \mathrm{E}+03$ & 28 & 35 & $-1.040 \mathrm{E}+03$ & 34 & 31 & $-4.000 \mathrm{E}+02$ \\
\hline 20 & 25 & $-4.000 \mathrm{E}+02$ & 28 & 37 & $0.000 \mathrm{E}+00$ & 34 & 33 & $-1.040 \mathrm{E}+03$ \\
\hline 20 & 26 & $-9.600 \mathrm{E}+02$ & 28 & 42 & $-4.000 \mathrm{E}+02$ & 34 & 35 & $0.000 \mathrm{E}+00$ \\
\hline 20 & 28 & $-8.000 \mathrm{E}+01$ & 29 & 20 & $-6.400 \mathrm{E}+02$ & 34 & 37 & $-8.000 \mathrm{E}+02$ \\
\hline 20 & 30 & $-1.280 \mathrm{E}+03$ & 29 & 27 & $0.000 \mathrm{E}+00$ & 34 & 39 & $-2.400 \mathrm{E}+02$ \\
\hline 20 & 32 & $0.000 \mathrm{E}+00$ & 29 & 29 & $-5.600 \mathrm{E}+02$ & 34 & 41 & $-8.000 \mathrm{E}+02$ \\
\hline 20 & 36 & $-8.000 \mathrm{E}+01$ & 29 & 35 & $-4.000 \mathrm{E}+02$ & 35 & 24 & $-8.000 \mathrm{E}+01$ \\
\hline 21 & 15 & $-8.000 \mathrm{E}+02$ & 29 & 36 & $-3.200 \mathrm{E}+02$ & 35 & 26 & $-4.000 \mathrm{E}+02$ \\
\hline 21 & 20 & $-2.400 \mathrm{E}+02$ & 29 & 37 & $-7.200 \mathrm{E}+02$ & 35 & 28 & $0.000 \mathrm{E}+00$ \\
\hline 21 & 24 & $-9.600 \mathrm{E}+02$ & 29 & 41 & $-8.000 \mathrm{E}+01$ & 35 & 30 & $-8.000 \mathrm{E}+01$ \\
\hline 35 & 34 & $-3.200 \mathrm{E}+02$ & 41 & 29 & $0.000 \mathrm{E}+00$ & 49 & 35 & $-5.600 \mathrm{E}+02$ \\
\hline 35 & 36 & $0.000 \mathrm{E}+00$ & 41 & 34 & $-1.200 \mathrm{E}+03$ & 49 & 43 & $-8.000 \mathrm{E}+02$ \\
\hline 35 & 37 & $-4.000 \mathrm{E}+02$ & 41 & 39 & $0.000 \mathrm{E}+00$ & 49 & 46 & $-5.600 \mathrm{E}+02$ \\
\hline \multicolumn{9}{|c|}{ Table 1 Continued } \\
\hline I & $\mathrm{J}$ & Discharge & $\mathrm{I}$ & $\mathrm{J}$ & Discharge & $\mathrm{I}$ & $\mathrm{J}$ & Discharge \\
\hline 35 & 38 & $-2.400 \mathrm{E}+02$ & 41 & 40 & $3.200 \mathrm{E}+02$ & 49 & 47 & $-4.000 \mathrm{E}+02$ \\
\hline 35 & 39 & $-9.600 \mathrm{E}+02$ & 41 & 41 & $-5.600 \mathrm{E}+02$ & 49 & 48 & $-3.200 \mathrm{E}+02$ \\
\hline 35 & 42 & $-3.200 \mathrm{E}+02$ & 42 & 28 & $-5.600 \mathrm{E}+02$ & 49 & 49 & $-2.400 \mathrm{E}+02$ \\
\hline 35 & 44 & $-5.600 \mathrm{E}+02$ & 42 & 31 & $-4.000 \mathrm{E}+02$ & 49 & 51 & $-1.840 \mathrm{E}+03$ \\
\hline 36 & 22 & $-4.800 \mathrm{E}+02$ & 42 & 41 & $-2.400 \mathrm{E}+02$ & 50 & 29 & $-8.800 \mathrm{E}+02$ \\
\hline 36 & 24 & $-4.000 \mathrm{E}+02$ & 42 & 42 & $-1.600 \mathrm{E}+02$ & 50 & 33 & $-9.600 \mathrm{E}+02$ \\
\hline
\end{tabular}




\begin{tabular}{|c|c|c|c|c|c|c|c|c|}
\hline 36 & 25 & $0.000 \mathrm{E}+00$ & 42 & 44 & $-7.200 \mathrm{E}+02$ & 50 & 37 & $-2.400 \mathrm{E}+02$ \\
\hline 36 & 30 & $-2.400 \mathrm{E}+02$ & 43 & 16 & $4.000 \mathrm{E}+02$ & 50 & 39 & $-7.200 \mathrm{E}+02$ \\
\hline 36 & 32 & $-4.000 \mathrm{E}+02$ & 43 & 22 & $-8.000 \mathrm{E}+01$ & 50 & 41 & $-1.040 \mathrm{E}+03$ \\
\hline 36 & 33 & $-2.400 \mathrm{E}+02$ & 43 & 34 & $-9.600 \mathrm{E}+02$ & 50 & 45 & $-1.600 \mathrm{E}+02$ \\
\hline 36 & 38 & $-4.800 \mathrm{E}+02$ & 43 & 38 & $-1.600 \mathrm{E}+02$ & 50 & 47 & $-7.200 \mathrm{E}+02$ \\
\hline 36 & 39 & $-4.800 \mathrm{E}+02$ & 43 & 41 & $-1.040 \mathrm{E}+03$ & 50 & 48 & $0.000 \mathrm{E}+00$ \\
\hline 36 & 41 & $-5.600 \mathrm{E}+02$ & 43 & 42 & $-7.200 \mathrm{E}+02$ & 50 & 49 & $-4.800 \mathrm{E}+02$ \\
\hline 37 & 19 & $-4.800 \mathrm{E}+02$ & 43 & 46 & $-5.600 \mathrm{E}+02$ & 51 & 21 & $-5.600 \mathrm{E}+02$ \\
\hline 37 & 21 & $-1.600 \mathrm{E}+02$ & 44 & 25 & $-1.280 \mathrm{E}+03$ & 51 & 32 & $-8.000 \mathrm{E}+01$ \\
\hline 37 & 30 & $-1.200 \mathrm{E}+03$ & 44 & 27 & $-2.400 \mathrm{E}+02$ & 51 & 44 & $-4.000 \mathrm{E}+02$ \\
\hline 37 & 32 & $-2.400 \mathrm{E}+02$ & 44 & 29 & $-4.000 \mathrm{E}+02$ & 51 & 46 & $-5.600 \mathrm{E}+02$ \\
\hline 37 & 37 & $-2.400 \mathrm{E}+02$ & 44 & 36 & $-1.600 \mathrm{E}+02$ & 51 & 47 & $-4.000 \mathrm{E}+02$ \\
\hline 37 & 39 & $-8.000 \mathrm{E}+01$ & 44 & 39 & $-1.040 \mathrm{E}+03$ & 51 & 49 & $-1.600 \mathrm{E}+03$ \\
\hline 37 & 40 & $-4.800 \mathrm{E}+02$ & 44 & 42 & $0.000 \mathrm{E}+00$ & 51 & 52 & $-4.800 \mathrm{E}+02$ \\
\hline 37 & 42 & $8.000 \mathrm{E}+01$ & 44 & 44 & $-3.200 \mathrm{E}+02$ & 52 & 25 & $-1.040 \mathrm{E}+03$ \\
\hline 37 & 43 & $0.000 \mathrm{E}+00$ & 45 & 24 & $-1.600 \mathrm{E}+02$ & 52 & 27 & $-4.000 \mathrm{E}+02$ \\
\hline 37 & 44 & $-3.200 \mathrm{E}+02$ & 45 & 31 & $-4.800 \mathrm{E}+02$ & 52 & 39 & $-8.000 \mathrm{E}+02$ \\
\hline 38 & 18 & $-1.440 \mathrm{E}+03$ & 45 & 33 & $-8.000 \mathrm{E}+01$ & 52 & 41 & $-1.600 \mathrm{E}+02$ \\
\hline 38 & 25 & $-1.040 \mathrm{E}+03$ & 45 & 36 & $-5.600 \mathrm{E}+02$ & 52 & 43 & $-1.520 \mathrm{E}+03$ \\
\hline 38 & 33 & $-3.200 \mathrm{E}+02$ & 45 & 45 & $-2.400 \mathrm{E}+02$ & 52 & 46 & $-5.600 \mathrm{E}+02$ \\
\hline 38 & 35 & $-7.200 \mathrm{E}+02$ & 46 & 23 & $-8.000 \mathrm{E}+01$ & 52 & 51 & $-4.000 \mathrm{E}+02$ \\
\hline 38 & 41 & $-8.000 \mathrm{E}+01$ & 46 & 26 & $-2.400 \mathrm{E}+02$ & 53 & 36 & $-4.000 \mathrm{E}+02$ \\
\hline 39 & 23 & $-8.000 \mathrm{E}+02$ & 46 & 28 & $-8.000 \mathrm{E}+01$ & 53 & 37 & $-8.000 \mathrm{E}+01$ \\
\hline 39 & 27 & $-3.200 \mathrm{E}+02$ & 46 & 38 & $0.000 \mathrm{E}+00$ & 53 & 42 & $-8.000 \mathrm{E}+01$ \\
\hline 39 & 39 & $-1.600 \mathrm{E}+02$ & 46 & 41 & $-1.760 \mathrm{E}+03$ & 53 & 48 & $-1.520 \mathrm{E}+03$ \\
\hline 39 & 40 & $-7.200 \mathrm{E}+02$ & 46 & 43 & $-1.600 \mathrm{E}+02$ & 53 & 52 & $-8.000 \mathrm{E}+01$ \\
\hline 39 & 41 & $-4.000 \mathrm{E}+02$ & 46 & 47 & $-1.200 \mathrm{E}+03$ & 54 & 22 & $0.000 \mathrm{E}+00$ \\
\hline 39 & 43 & $-8.800 \mathrm{E}+02$ & 46 & 50 & $-9.600 \mathrm{E}+02$ & 54 & 32 & $-1.600 \mathrm{E}+02$ \\
\hline 39 & 44 & $-8.800 \mathrm{E}+02$ & 47 & 30 & $-4.000 \mathrm{E}+02$ & 54 & 46 & $-1.360 \mathrm{E}+03$ \\
\hline 40 & 26 & $-1.600 \mathrm{E}+02$ & 47 & 33 & $-8.000 \mathrm{E}+01$ & 54 & 48 & $-4.800 \mathrm{E}+02$ \\
\hline 40 & 27 & $-8.000 \mathrm{E}+01$ & 47 & 37 & $-7.200 \mathrm{E}+02$ & 54 & 50 & $-8.000 \mathrm{E}+01$ \\
\hline 40 & 36 & $-1.840 \mathrm{E}+03$ & 47 & 45 & $-1.600 \mathrm{E}+03$ & 55 & 24 & $-8.000 \mathrm{E}+02$ \\
\hline 40 & 37 & $-8.800 \mathrm{E}+02$ & 47 & 49 & $-2.400 \mathrm{E}+02$ & 55 & 30 & $-1.520 \mathrm{E}+03$ \\
\hline 40 & 38 & $-8.000 \mathrm{E}+01$ & 48 & 30 & $-6.400 \mathrm{E}+02$ & 55 & 37 & $-3.200 \mathrm{E}+02$ \\
\hline 40 & 41 & $-7.200 \mathrm{E}+02$ & 48 & 35 & $-1.360 \mathrm{E}+03$ & 55 & 40 & $-7.200 \mathrm{E}+02$ \\
\hline 40 & 42 & $-1.280 \mathrm{E}+03$ & 48 & 40 & $-1.040 \mathrm{E}+03$ & 55 & 51 & $-8.000 \mathrm{E}+02$ \\
\hline 40 & 43 & $-1.200 \mathrm{E}+03$ & 48 & 42 & $-8.800 \mathrm{E}+02$ & 56 & 28 & $-8.000 \mathrm{E}+01$ \\
\hline 40 & 46 & $-7.200 \mathrm{E}+02$ & 48 & 46 & $-8.000 \mathrm{E}+01$ & 56 & 42 & $-8.000 \mathrm{E}+01$ \\
\hline 41 & 22 & $-6.400 \mathrm{E}+02$ & 48 & 49 & $-8.800 \mathrm{E}+02$ & 56 & 45 & $-1.600 \mathrm{E}+03$ \\
\hline 41 & 25 & $-9.600 \mathrm{E}+02$ & 49 & 26 & $-8.000 \mathrm{E}+01$ & 56 & 47 & $-7.200 \mathrm{E}+02$ \\
\hline 41 & 26 & $-2.400 \mathrm{E}+02$ & 49 & 32 & $0.000 \mathrm{E}+00$ & 56 & 53 & $-1.200 \mathrm{E}+03$ \\
\hline 57 & 37 & $-1.600 \mathrm{E}+02$ & 60 & 57 & $0.000 \mathrm{E}+00$ & 66 & 56 & $-8.000 \mathrm{E}+01$ \\
\hline
\end{tabular}




\begin{tabular}{|l|l|l|l|l|l|l|l|l|}
\hline 57 & 49 & $-1.600 \mathrm{E}+02$ & 61 & 40 & $0.000 \mathrm{E}+00$ & 67 & 53 & $-3.200 \mathrm{E}+02$ \\
\hline 57 & 51 & $-1.600 \mathrm{E}+03$ & 61 & 49 & $-5.600 \mathrm{E}+02$ & 67 & 58 & $-4.800 \mathrm{E}+02$ \\
\hline 57 & 56 & $-6.400 \mathrm{E}+02$ & 61 & 58 & $-3.200 \mathrm{E}+02$ & 68 & 61 & $-2.400 \mathrm{E}+02$ \\
\hline 58 & 29 & $-3.200 \mathrm{E}+02$ & 62 & 52 & $-8.800 \mathrm{E}+02$ & 69 & 58 & $-1.600 \mathrm{E}+02$ \\
\hline 58 & 43 & $-8.000 \mathrm{E}+01$ & 62 & 56 & $-9.600 \mathrm{E}+02$ & 70 & 63 & $-8.000 \mathrm{E}+02$ \\
\hline 58 & 45 & $-3.200 \mathrm{E}+02$ & 62 & 60 & $0.000 \mathrm{E}+00$ & 70 & 65 & $-1.200 \mathrm{E}+03$ \\
\hline 58 & 53 & $-1.200 \mathrm{E}+03$ & 63 & 42 & $-3.200 \mathrm{E}+02$ & 70 & 68 & $-1.600 \mathrm{E}+02$ \\
\hline 58 & 57 & $-1.600 \mathrm{E}+02$ & 63 & 47 & $-1.040 \mathrm{E}+03$ & 71 & 59 & $-5.600 \mathrm{E}+02$ \\
\hline Table 1 Continued & & & & & & \\
\hline 59 & 32 & $-2.400 \mathrm{E}+02$ & 63 & 53 & $-2.400 \mathrm{E}+02$ & 71 & 60 & $-2.400 \mathrm{E}+02$ \\
\hline 59 & 46 & $-9.600 \mathrm{E}+02$ & 63 & 58 & $-6.400 \mathrm{E}+02$ & 73 & 65 & $-1.040 \mathrm{E}+03$ \\
\hline 59 & 50 & $0.000 \mathrm{E}+00$ & 64 & 56 & $-8.000 \mathrm{E}+01$ & 73 & 67 & $-3.200 \mathrm{E}+02$ \\
\hline 59 & 55 & $-1.680 \mathrm{E}+03$ & 64 & 58 & $-1.040 \mathrm{E}+03$ & 75 & 68 & $-4.000 \mathrm{E}+02$ \\
\hline 60 & 37 & $0.000 \mathrm{E}+00$ & 65 & 58 & $0.000 \mathrm{E}+00$ & 75 & 69 & $-1.360 \mathrm{E}+03$ \\
\hline 60 & 43 & $-1.280 \mathrm{E}+03$ & 65 & 60 & $-7.200 \mathrm{E}+02$ & 75 & 71 & $-8.000 \mathrm{E}+01$ \\
\hline 60 & 53 & $-3.200 \mathrm{E}+02$ & 65 & 61 & $-1.600 \mathrm{E}+02$ & & \\
\hline 60 & 55 & $-1.120 \mathrm{E}+03$ & 66 & 50 & $-1.120 \mathrm{E}+03$ & & \\
\hline
\end{tabular}

Table 1. Raw index (I), Column index (J), and optimum pumping rate $\left(\mathrm{m}^{3} /\right.$ day) in the study area

\begin{tabular}{|l|l|l|l|l|}
\hline \multirow{2}{*}{ Control point No. } & \multirow{2}{*}{ Location (I,J) } & Hydraulic Head (m) & Upper Bound & Head Value \\
\cline { 2 - 5 } 1 & 20,13 & 2.1 & 2.5 & 2.4 \\
\hline 2 & 32,13 & 2.7 & 3.1 & 2.8 \\
\hline 3 & 43,13 & 1.4 & 1.8 & 1.5 \\
\hline 4 & 7,34 & 1.6 & 2.0 & 1.8 \\
\hline 5 & 29,34 & 1.5 & 1.9 & 1.7 \\
\hline 6 & 49,34 & 1.1 & 1.5 & 1.2 \\
\hline 7 & 7,55 & 1.2 & 1.6 & 1.5 \\
\hline 8 & 33,55 & 1.0 & 1.4 & 1.1 \\
\hline 9 & 55,55 & 1.1 & 1.5 & 1.4 \\
\hline
\end{tabular}

Table 2. Distribution of hydraulic heads based on the optimized pumping rates

\section{Conclusions}

Two-dimensional mathematical model is presented for Safawn-Zubair area, south of Iraq. The modeling is fixed for upper layer only (unconfined aquifer), it is assumed that the base of the upper aquifer is an impermeable boundary and heads do not vary in the vertical direction. The calibrated values of hydraulic conductivity vary over the range $(15-150) \mathrm{m} /$ day. While, the calibrated values of specific yield vary over the range $(0.125-0.45)$. The optimum value of pumping rate is equaled to $0.636925 \mathrm{E}+8 \mathrm{~m}^{3} /$ year. The number of active wells in optimal solution is 312 wells, so many wells in the study area that occupy incorrect positions, which are affected on the process of pumping groundwater.

\section{Conflict of Interest}

No conflict of interest was reported by the author. 


\section{References}

1. Gleick, P.H., 2000. The world's water 2000-2001, the biennial report on freshwater resources. Washington, DC, Island press.

2. Gill, G.J., 1996. Agriculture and natural resources management, Journal of Asian Economics 7(2): 317-332.

3. Haddad, R.H., 1977, Hydrogeology of Safwan area, south of Iraq, Unpub, Ph.D. thesis ,Univ. College London, $233 p$.

4. Hassan, H.A.,Ismail,S.K., and Al-Dabbas ,M.,1989,Regional hydrogeological condition of Dibdibba basin, southern Iraq,Jour. Agr. Water Resour. Res.,vol.8,No.1,pp 167-180.

5. Al-Jawad,S.B,Ayob,M.S,Khalil,S.,and Al-Ridha, N.H,1989,Hydraulic properties of Dibdibba sandstone using pumping tests data in large diameter wells ,Proc, ${ }^{\text {th }}$ Sci.,Conf,SRC.Iraq,vol.1 part 3,pp 135-145.

6. Al-Suhail,Q.A,1999, Geochemical evaluation of groundwater system of Dibdibba aquifer,southern Iraq,Basrah J. of Sci.,vol.17,No.1,pp 63-72.

7. Buday, T., 1980. The regional geology of Iraq, stratighraphy and paleogeolography. Vol.1, Dar-Al-Kutib Pub.House, Univ. of Mousl, 445p.

8. Macfadyen, N. A., 1938 "Water Supplies in Iraq", Publication No.1, Ministry of Economics and Communications, Iraq, Geology DEPT., Government of Iraq, Baghdad printing press.

9. Al-Kubaisi, Q. Y., 1999 "Quaternary-Tertiary Hydrogeologic Boundary Condition at Safwan-Zubair Area, South of Iraq", Iraq Jour. Scie., Vol.40, No.3, pp. 21-28.

10. Al-Aboodi A. H., Khudhair K. M., Al-Aidani A. S., 2016 Prediction of Groundwater Level in Safwan-Zubair Area Using Artificial Neural Networks, Basrah Journal for Engineering Sciences, vol. 16, no. 1.

11. Zheng, C. and Wang P.P., 2003, A Modular Groundwater Optimizer Incorporating MODFLOW/MT3DMS. The University of Alabama, documentation and user's guide, $119 \mathrm{p}$. 